\title{
How macro-level sampling affects micro-level arguments: a rejoinder to Steven Casper
}

\section{Andrea M. Herrmann*}

Innovation Studies Group, Utrecht University, Utrecht, The Netherlands

*Correspondence: a.herrmann@geo.uu.nl

\begin{abstract}
Keywords: firm strategy, innovation, institutional political economy, methodology

JEL classification: P16 political economy, L21 business objectives of the firm, L65 industry studies, chemicals, rubber, drugs, biotechnology, M13 new firms, start-ups
\end{abstract}

\section{Introduction}

For scientists, it is a rewarding experience when our research findings are taken seriously and become the object of an international scientific debate. I thus gratefully acknowledge the interest which Steven Casper has taken in my work by responding in a recent volume of the Socio-Economic Review (Casper, 2009) to the results which Knut Lange (Lange, 2009) and myself (Herrmann, 2008a) had published in previous issues. My article did not address Casper's research directly. However, like the work of Lange, my findings raise questions about Casper's results ${ }^{1}$ as they arrive at opposite conclusions regarding the sustainability of radically innovative firms in Germany.

Drawing on institutional theory, Casper starts from the observation that 'institutions strongly influence the ... innovation strategies of ... firms' (Casper, 2000, p. 888). More precisely, 'German institutional frameworks produce obstacles to firms in radically innovative industries, but... [facilitate the development of incrementally innovative] industries that rely on continuous process innovations and product improvements'. Accordingly, '[i]ndustry specialization data reveal that German firms overwhelmingly specialize... [in incrementally innovative] segment[s], while firms in the [United Kingdom and] the United States... tend to dominate the [radically innovative] segment[s]' (ibid). Most importantly,

\footnotetext{
${ }^{1}$ See Casper et al. (1999), Casper (2000, 2007), Casper and Matraves (2003) and Casper and Whitley (2004).
} 
Casper argues that firms in Germany which nevertheless embarked on strategies of radical product innovation (RPI) are unsuccessful and not sustainable in the long run. 'An institutional framework capable of sustaining radically innovative biotechnology companies does not exist in Germany' (Casper, 2007, p. 104), which explains their 'poor performance' (ibid, p. 182).

While Lange and myself agree that national institutions support some product market strategies and hinder others, we disagree with Casper that firms must choose strategies in line with national institutional advantages. Contrary to Casper, I illustrate that and how radically innovative firms compete successfully despite comparative institutional disadvantages of Germany's financial and labour markets. The remedies are straightforward. Firms defect from national institutions and acquire scarce input factors from abroad or via individual contracts (Herrmann, 2008a, $b$ ).

The question why the findings of Casper differ from those of Lange and myself is of scientific relevance. This is particularly true as my explanation below suggests that differences between proponents and sceptics of the 'varieties-of-capitalism' (VoC) literature may stem from different sampling approaches that go beyond the identification of radically innovative firms in Germany.

Casper's explanation (2009, p. 211) of our discrepancies is that 'there is an important selection bias in both [Lange's and my own] studies'. Casper acknowledges that radically innovative firms exist in Germany, which compete by defecting from national institutions, as illustrated by Lange and myself. But, in his view, this explanation holds only for a small 'pool of [successful] German companies' (ibid, p. 213) which I allegedly sampled by selecting 'primarily [those] companies that had successfully invented a new chemical entity'. According to Casper, his less optimistic assessment of radical innovators in Germany is more realistic, because it is based on a comprehensive sample 'assessing the winners and losers' (ibid).

My explanation is different. In my view, our findings are opposed: first, because we use different measures to identify competitive strategies of firms, whereby Casper's measure seems to underestimate the number of radically innovative firms in Germany. Second, we use different indicators of corporate success, whereby the validity of the indicators proposed by Casper seems debatable. Accordingly, I here respond to Casper's article, first, by illustrating the differences in our sampling approaches (Section 1) and, second, by discussing the success measures we used (Section 2). This leads me to conclude, first, that VoC researchers who identify competitive strategies through macro-level indicators risk overestimating the extent to which firms within one economy pursue similar strategies. Second, I conclude that Casper is misled to depict my results as biased due to an alleged analytical focus on successful firms. 


\section{Identifying competitive strategies: at the macro- or the micro-level?}

To identify competitive strategies, Casper uses a macro-level indicator, namely a firm's sub-sector or its industry. Within the biotech industry, Casper typically distinguishes between therapeutics producers, which he deems to be radically innovative, and platform-technology providers, which he argues to be incrementally innovative. Accordingly, he finds that most biotech firms in Germany specialize and deliver incrementally innovative platform technologies, whereas most biotech firms in the UK specialize and produce radically innovative therapeutics. ${ }^{2}$ Elsewhere, Casper suggests a similar distinction between pharmaceutical companies which are less, or incrementally, innovative and biotechnology firms which are radically innovative (Casper and Matraves, 2003, in particular Section 3). Irrespective of whether the distinction is made between therapeutics producers and platform-technology deliverers within the biotech industry, or between biotech and pharmaceutical firms within the drug-making business, the simplifying assumption underlying Casper's sampling approach—using a firm's subsector or industry to identify its strategy-remains the same. All firms active in the same sub-sector or, respectively, industry are found to pursue the same competitive strategy.

But is it not more likely that firms in the same industry differ in their technology-intensity and, hence, in the strategies they pursue? To allow for this possibility, I used a combined micro-level indicator and identified how many firms in Germany and the UK pursue strategies of radical and incremental innovation. ${ }^{3}$ Similar to Casper, I analyzed drug-makers, including biotech and traditional pharmaceutical firms, and combined their respective focus on upstream or midstream activities of the value chain with their development of new chemical entities (NCEs) or already discovered molecules (non-NCEs) (for details, see Herrmann, 2008b, Chapter 2, 2008c). Importantly, this microlevel measure revealed that firms within the same industry actually pursue different strategies.

How do Casper's macro- and my micro-level measurements of competitive strategies affect the firm samples obtained? I answered this question in a separate article (Herrmann, 2008c) and will briefly sketch my argument here. Most importantly, the number of drug-makers that are found to pursue strategies of RPI and incremental product innovation (IPI) in Germany and the UK differs as

\footnotetext{
${ }^{2}$ See Casper et al. (1999), Casper (2000, 2007, in particular Chapter 6) and Casper and Whitley (2004).

${ }^{3}$ To provide a complete picture, I also sampled firms in Italy and firms pursuing product-imitation strategies. Since neither group is relevant for my discrepancies with Casper's sampling approach, I here abstain from further illustrations.
} 
a function of the sampling approach chosen. Whenever a firm's industry ${ }^{4}$ (macro-level measurement) is employed as strategy measure, specialization patterns emerge. The reason, simply, is that biotech firms were-during the investigation period-relatively more numerous in the UK than in Germany, while the opposite applies for pharmaceutical firms. Casper therefore finds that the majority of British firms pursue RPI strategies, whereas most German firms specialize in IPI strategies. The use of a more fine-grained micro-level indictor (combining a firm's innovativeness with its value-chain focus) leads to balanced results, because radically innovative pharmaceutical firms are identified as RPI strategists, while incrementally innovative biotech firms are found to pursue IPI strategies. I therefore find that roughly the same number of firms in Germany and the UK pursues RPI and IPI strategies.

Given that Casper and myself identify different strategies for a small proportion of companies (namely for all radically innovative pharmaceutical and incrementally innovative biotech firms), ${ }^{5}$ the statistical significance of the specialization patterns identified changes: Casper finds significant specialization trends. I do not. This, in turn, leads us to adopt different research foci. Casper focuses on the majority of firms which, according to his sampling approach, pursue RPI strategies in the UK and IPI strategies in Germany, and he explains how these companies compete due to the support of national institutions. I, in contrast, explain how a plurality of firms in each country competes despite comparative institutional disadvantages.

Two aspects are noteworthy. First, had I used Casper's macro-level approach, my samples would have shown the same specialization patterns as those of Casper. Second, there seem to be good methodological reasons not to use macrolevel indicators for measuring micro-level phenomena, including competitive strategies of firms. Ever since the seminal article of Robinson (1950), numerous methodologists have warned not to test theories on micro-level relationships through macro-level data, because important information on individual cases is lost when the latter are aggregated at a higher level. One might thus wonder whether the strategy specialization patterns identified by Casper are indeed representative of the micro-level phenomenon he intends to measure. His less finegrained macro-level indicator seems to underestimate the share of RPI strategists in Germany and IPI firms in the UK. On a more general level, one might even

\footnotetext{
${ }^{4}$ In the following, the 'industry' can be read as a synonym for 'sub-sector', while 'pharmaceutical' and 'biotech firms' are synonyms for 'platform-technology' and 'therapeutics companies'.

${ }^{5}$ In the real-world data set I used, different strategies are identified for about $10 \%$ of RPI and IPI strategists in Germany and the UK alike. This means that the difference between the absolute share of RPI and IPI firms in each country increases by $20 \%$ whenever the firms' industry, rather than their technology intensity, is used to identify competitive strategies (see Herrmann, 2008c).
} 
question a broader VoC literature which identifies competitive strategies through industry indicators: are the revealed specialization patterns merely a result of a rough strategy measure?

In sum, different strategy indicators and, hence, sampling approaches are at the basis of Casper's and my discrepancies regarding the sustainability of RPI strategists in Germany. In addition, we employ different measures of corporate success.

\section{Indicators of corporate success and their validity}

Aware that only sustained competitiveness indicates whether firms can compete despite comparative institutional disadvantages, I explicitly analyzed whether 'firms choosing a non-conformist strategy are punished ... [in that the difficulty to circumvent national institutions leads to] failure in the long run'. (Herrmann, 2008b, p. 135; also Herrmann, 2009). To answer this question, I assessed two different firm samples and studied both: the frequency of bankruptcies, mergers, acquisitions and corporate stability of firms since their foundation year (diachronic analyses), as well as the performance of firms in several accounting ratios which financial analysts typically use for corporate evaluations (synchronic analyses). The results of both synchronic and diachronic analyses lead to similar conclusions. Firms that pursue strategies unsupported by national institutions do not perform worse than firms that pursue strategies in line with comparative institutional advantages. This is particularly true for RPI strategists in Germany which perform slightly better on most indicators than their British counterparts.

Throughout his article, Casper (2009) points to three measures of corporate success: company size, the number of firms that pursue institutionally unsupported strategies, and the extent of NCE development. The validity of all three indicators seems debatable. Regarding company size, Casper suggests that radically innovative firms in Germany are less successful because many remain small: 'Over 40\% of employment within German biotechnology is within the 30 largest firms (i.e. the successful firms)' (ibid, p. 211). However, numerous studies (for example Utterback, 1994) have demonstrated that radical innovations are typically proposed by small start-up companies, because radically new goods often make existing products obsolete. Incumbent firms have therefore little interest in pursuing a strategy that accelerates the decline of their own products. Consequently, small company size seems to be an indication of success rather than failure in RPI.

Casper (2009, pp. 212-213) furthermore suggests that the limited number of RPI strategists in Germany is an indication of their failure. ${ }^{6}$ More concretely,

${ }^{6}$ Also Casper (2000, 2007, Chapters 4 and 6) and Casper and Whitley (2004). 
Casper highlights the incapability of Germany's RPI strategists to obtain 'either the financing or the industry-specific human capital needed to compete successfully', which implies that these firms will sooner or later go bankrupt. Two problems are related to measuring the success of RPI firms by their sheer number. First, as illustrated in Section 1, this number depends on the strategy measure employed, whereby Casper's measurement seems to underestimate the share of RPI strategists in Germany. Second, as soon as their balance sheet performance is considered, German RPI firms prove to be very successful even though and, possibly, because they must make particular efforts to secure all necessary input factors (Herrmann, 2008b, p. 20, pp. 135-156, 164-165). While I agree with Casper that defecting from national institutions is not without difficulties, I disagree that these difficulties and, ultimately, the sheer number of firms pursuing institutionally unsupported strategies constitute valid success measures.

Finally, Casper suggests that the invention of NCEs is an indication of corporate success (see also Casper and Matraves, 2003, p. 1872-1876). Consequently, Casper portrays my research as biased, because it allegedly studies only successful RPI firms, i.e. 'companies that had successfully invented a new chemical entity' (Casper, 2009, p. 211). This statement requires rectification in two respects. First, it is debatable whether inventions of NCEs constitute a valid measure of corporate success. NCE development points to the technological intensity of a firm's competitive strategy rather than to its success (see Section 1). Firms which invent NCEs are radically innovative but not necessarily successful.

Second, the RPI firms I studied are not primarily inventors of NCEs, but more often biotech firms that develop non-NCEs while focusing on upstream activities of the value chain. I thoroughly illustrated my sampling approach in several publications (Herrmann, 2008c), most notably in a book which summarizes my findings on whether, how and how successfully firms compete despite comparative institutional disadvantages (Herrmann, 2008b). Given that my article in the Socio-Economic Review elaborates on how these firms compete, I gave only a brief overview of my sampling approach, which seems to convey the impression that I studied primarily RPI firms inventing NCEs. This is an unfortunate misunderstanding as my sample actually includes 'not a single firm ... that merely develops or out-licenses pharmaceutical products based on an NCE' (ibid, p. 43).

In summary, I agree with Casper that our findings on the success of Germany's RPI strategists differ because we use different sampling approaches. It is however incorrect that I analyzed primarily successful RPI firms inventing NCEs. My sample includes successful and unsuccessful RPI strategists alike and my results are thus founded on a representative selection of firms. Instead, our samples differ because Casper identifies a higher share of Germany's drug-makers as IPI firms, and of British drug-makers as RPI strategists, than I do. This leads us to choose different research foci and indicators of corporate success. 


\section{Acknowledgements}

I wish to thank Nicole Bolleyer, Bob Hancké, Simcha Jong, Knut Lange, George Menz, Erik Stam and Neil Thompson for their comments on previous versions of this article. They all provided valuable feedback without taking sides on substance.

\section{References}

Casper, S. (2000) 'Institutional Adaptiveness, Technology Policy, and the Diffusion of New Business Models: The Case of German Biotechnology', Organization Studies, 21, 887-914.

Casper, S. (2007) Creating Silicon Valley in Europe: Public Policy towards New Technology Industries, Oxford, Oxford University Press.

Casper, S. (2009) 'Can New Technology Firms Succeed in Coordinated Market Economies? A Response to Herrmann and Lange', Socio-Economic Review, 7, 209-215.

Casper, S. and Matraves, C. (2003) 'Institutional Frameworks and Innovation in the German and UK Pharmaceutical Industry', Research Policy, 32, 1865-1879.

Casper, S. and Whitley, R. (2004) 'Managing Competences in Entrepreneurial Technology Firms: a Comparative Institutional Analysis of Germany, Sweden, and the UK', Research Policy, 33, 89-106.

Casper, S., Lehrer, M. and Soskice, D. (1999) 'Can High-Technology Industries Prosper in Germany? Institutional Frameworks and the Evolution of the German Software and Biotechnology Industries', Industry and Innovation, 6, 5-24.

Herrmann, A. M. (2008a) 'Rethinking the Link between Labour Market Flexibility and Corporate Competitiveness: a Critique of the Institutionalist Literature', Socio-Economic Review, 6, 637-669.

Herrmann, A. M. (2008b) One Political Economy, One Competitive Strategy? Comparing Pharmaceutical Firms in Germany, Italy, and the UK, Oxford, Oxford University Press.

Herrmann, A. M. (2008c) 'Contrasting the Resource-based View and Competitiveness Theories: How Pharmaceutical Firms Choose to Compete in Germany, Italy and the UK', Strategic Organization, 6, 343-374.

Herrmann, A. M. (2009) 'On the Choice and Success of Competitive Strategies', Competition and Change, 13, 3-28.

Lange, K. (2009) 'Institutional Embeddedness and the Strategic Leeway of Actors: The Case of the German Therapeutical Biotech Industry', Socio-Economic Review, 7, 181-207.

Robinson, W. S. (1950) 'Ecological Correlations and the Behavior of Individuals', American Sociological Review, 15, 351-357.

Utterback, J. M. (1994) Mastering the Dynamics of Innovation - How Companies Can Seize Opportunities in the Face of Technological Change, Boston, MA, Havard Business School Press. 